\title{
MEASURING SERVICE QUALITY IN GAUHATI UNIVERSITY LIBRARY: A SERVQUAL ANALYSIS
}

\author{
Digbijoy Das \\ Assam Womens University, Assam, India \\ Kaushik Handique \\ Assam Womens University,Assam, India
}

\begin{abstract}
Information and Communication Technology had made revolutionary changes in all housekeeping activities and services in our library. In the present scenario, libraries have to face crisis of survival to competition from publishers, vendors, online services and internet. Customer satisfaction is the basic goal of any organization. Measuring customer/user satisfaction has become one of the most popular marketing strategies in all service industries, as well as libraries.
\end{abstract}

Key words: Servqual, Service Quality, Gauhati University.

Cite this Article: Digbijoy Das and Kaushik Handique, Measuring Service Quality in Gauhati University Library: A Servqual Analysis, International Journal of Management, 11(12), 2020, pp. 884-895.

http://iaeme.com/Home/issue/IJM?Volume=11\&Issue=12

\section{INTRODUCTION}

Information and Communication Technology had made revolutionary changes in all housekeeping activities and services in our library. In the present scenario, libraries have to face crisis of survival to competition from publishers, vendors, online services and internet. Customer satisfaction is the basic goal of any organization. Measuring customer/user satisfaction has become one of the most popular marketing strategies in all service industries, as well as libraries.

Assessment of university library services should be considered as a management tool, purposely applied to determine how library is serving the needs and expectations of its users effectively and efficiently. As well as identifying the strengths and weakness of its services in order to recommend ways of sustaining and improving the quality of service delivery in an institution. The extent to which library service quality are assess depends on the availability of information resources (both printed \& electronic), services rendered, and facilities utilization by the university library users. The currency and relevancy of the information resources 
properly arrange on shelves, the usefulness of its catalogs and finding tools in providing access to its collection, the ability and cooperation of the library staff to use the facilities available in bringing these information resources and services to the attention of the users, the attitude of the staff in rendering services, are some of the requirements necessary for measuring service quality.

Apart from availability and accessibility of information resources, the application of facilities in providing services such circulation, technical, acquisition, serial, reference, reserve, reprographic, e-library, managerial etc facilitate prompt service delivery. Gama, (2013) opined that university libraries users are generally scholars and students whose use of the library facilities assists them to write papers, form class lectures, write assignments, enhance staff productivity and efficiency in discharging their duties and responsibilities, etc. The extent to which the library is used reflects the degree of user satisfaction which can be measured through the use of questionnaires or interviews, etc (Kulkarni \& Deshpande, 2016).

Satisfying users' needs in the university libraries has been the primary objective of both the libraries and the librarians. Every year, new students come to the university with different needs and expectations. Besides, new technology, databases, and more innovative systems for accessing information, have made the library more complicated and challenging for librarians and users alike. The unfriendly treatment from library staff towards users, the abundance of resources available, and the difficulty in being able to identify these resources also create problems for users. The inability to easily identify the specific use of a library's services because of the new technologies, inadequate and non-functioning of some library facilities, and the difficulty to access information sources can all contribute to user dissatisfaction among university library users. Peris \& Otike, (2016) asserted that university libraries today are faced with the challenges of infrequent or non-use of resources largely because of inadequate awareness, perceived lack of relevance, lack of time, distance, lack of skills in the use of electronic resources, having personal books and/or borrowing books from friends, access to the internet from home, slow internet, noisy and inappropriate study areas; inadequate collection; poorly managed information resources; unhelpful disinterested staff, and unfriendly users conveniences couple with other competitive sources of information that seem to be threatening the role of university libraries.

Therefore, it has become necessary for university libraries to adopt a more strategic approach beside the initial ones been used in order to know their users' perceptions since libraries exist purposely to serve users. Hence, there is a need for university libraries to understand their user needs and satisfy them. This research, used users (postgraduate students) to assess library service quality by considering several important quality attributes in university libraries such as availability $\&$ accessibility of information resources, library staff behavior and the library building and its environment. The identified attributes that have a lower satisfaction level should be improved while the strong one should be sustained by the university library.

\section{BRIEF HISTORY OF GAUHATI UNIVERSITY LIBRARY}

The Krishna Kanta Handiqui Library was established to serve the needs of the students, teachers and research scholars of the university. It not only helps in supporting the classroom instructional programmes of the university, but also unfolds the horizon of knowledge in regard to the different research programmes carried out by the university. The University Library started its functioning in 1948. In 1982, the university library was renamed as Krishna Kanta Handiqui Library after the death of its first Vice Chancellor Professor Krishna Kanta Handiqui an Orientalist of world fame. The personal collection of Prof Handiqui consists of 7593 volumes of books generously donated by him to Gauhati University is a precious and priceless 
possession of the library. The collection includes books on 11 (eleven) different languages like English, French, German, Greek, Italian, Latin, Pali, Prakrit, Russian, Sanskrit and Spanish.

\subsection{KKH Library at a Glance Holdings}

- Books - 269369 volumes

- Bound periodicals - 34495 volumes

- Theses -3704 nos.

- Report literature -4276 nos.

- Dissertations - 5601 nos.

- Manuscripts - 4500 nos.

- K. K. Handiqui Collection - 7593 volumes in 11 (eleven) languages.

- Digitized Manuscripts - 150000 pages

- Digitized Theses - 852524 pages

\subsection{Special Collections}

- K K Handiqui Collection

- Dr Bhupen Hazarika Corner

- Vivekananda Corner

- Gandhi Collection

- Dr MaheswarNeogCollection

- Aurobindo Corner

- Nehru Corner

- Women's Corner

- Collection of Manuscripts on Sanchipat, Tulapat etc.

- Back Volumes of Journals and Selected Newspapers

- Textbook Corner

- NE Corner

- UN Corner

- Thailand Corner

\subsection{Facilities Available}

Internet, Xerox, Webopac for access to library, OPAC through Campus LAN, ETD (Electronic Theses and Dissertations) through Shodhganga, e-Journal browsing through UGC-Infonet, IEEEXplore, Manupatra, J-Gateplus, Online Abstracting and Indexing database viz. SCOPUS.

\section{RESEARCH GAP AND RESEARCH PROBLEM}

According to Calvert (2001), Service Quality is "to examine the difference between customer"s expectation and customer"s perceived sense to actual performance ecee. To ensure quality to Information services Library and Information Centres assessing their Service Quality with help of multidimensional research instrument called SERVQUAL designed to capture consumer expectations and perceptions of a service along the five dimensions that are believed to represent service quality. 
Hernon (2002) concluded that service quality focuses on the interaction between customers and service providers, and the gap or difference between expectations about service provision and perception about how the service was actually provided.

According to library professionals, some librarians think that they can decide the quality of the library service for their users, thinking that they know their users' needs. They also think that users cannot judge the quality of service and they do not know what they want and what would be more useful to them (Kulkarni \& Deshpande, 2012). However, such opinions are immaterial because the criteria that counts in evaluating service quality are defined by users. Only users judge service quality; all the other judgments are essentially irrelevant because the most important stakeholders are the users (Parasuraman A. et al, 1985). Without users the library is just a 'warehouse' of information. The users are the ultimate consumers of the library services. The library's success should be measured not in terms of what it has (inputs) but of what it does, the activities it supports, its outputs for example circulation transactions, reference questions answered, classes taught and students enrolled. This also explains the significant role of the library staff, as they have to treat the users as important guests and in that way they will contribute to their satisfaction (Forrest, 2009).

\section{SERVQUAL:}

SERVQUAL is a multiple item scale i.e, questionnaire or measurement scale introduced in 1988 by A. Parasuraman, Valarie A., Zeithaml and Leonard L Berry as an instrument for assessing customer perceptions of service quality in service organization. They mentioned that It is the solution to measure service quality in terms of provideres performance with respect to customers expectation. According to Nitechi (1996), SERVQUAL is a mechanism to shift the assessment of quality of a library from the traditions of measuring collections, size and counting incidents of its users to begin investigating how the provision of services relates to the library user"es service quality expectations. SERVQUAL has been used in various service industries including academic, public and special libraries as stated by Hernon in 2002.The SERVQUAL scale constitutes an important landmark in the service quality literature and has been extensively applied in different service settings.

\subsection{The Model of Service Quality}

A Parasuraman, Valarie, A., Zeithaml and Lan Berry (1985) a group of American authors developed the model of service quality popularly known as Gaps Model. The Model identifies the principal dimensions or components of service quality and proposes a scale for measuring it (SERVQUAL) and suggests possible causes of service quality problems. The designers of Gap Model initially identified ten dimensions and reduced as five - namely,

- Reliability: It is the ability to perform the promised service accurately and dependably.

- Assurance: It is the courtesy and knowledge of the employees and their ability to inspire trust and confidence.

- Tangible: The appearance of facilities, equipment's, personnel and communication materials.

- Empathy: The provision of caring and individualized attention to customers and

- Responsiveness: It is the willingness to help the customers and provide them prompt service.

The first letter of each of the five dimensions formed an acronym, RATER which is used as an aid to recall. 
The model of service quality is built on the expectancy- confirmation paradigm which suggests that consumers perceive quality in terms of their perceptions of how well a given service delivery meets their expectations of that delivery(r). Thus service quality can be conceptualized as $\mathrm{SQ}=\mathrm{P}-\mathrm{E}$ Where, $\mathrm{SQ}$ is the Service Quality $\mathrm{P}$ is the individuals perceptions of given service delivery $\mathrm{E}$ is the individuals expectations of a given service delivery

\subsection{The Objective of the Study:}

The study provides some insights on how users rate the service quality of Krishna Kanta Handiqui Library system.

The main objective of the study is:

- To measure the overall service quality of Krishna Kanta Handiqui Library system using SERVQUAL

- To identify the gap between users expectations and perceptions of library service quality.

\section{LITERATURE REVIEW:}

There are many relevant studies have been carried out on Measuring Service Quality among University Libraries using SERVQUAL in India and abroad.

Service quality in Covenant University Lecture Theatre was done by Irohan, and et al., (2017) using the modified version of SERVQUAL. A cross sectional survey was conducted among students, faculties who lecture in the theatre and faculties who have offices in the lecture theatre. The service quality of facilities provided in the lecture theatre of Covanent University, Ota Ogun, state of Nigeria. Findings of the study revealed that all dimensions showed an overall negative average tangible reliability responsiveness, assurance and empathy. This signifies perceptions being below expectations there by placing the end users in an unsatisfactory level.

Malik and Malik (2015) conducted a case study in Public University library of Pakistan. The main aim of the study was to determine the gap between perceived and expected service quality of COMSATS Institute of Information Technology (CIIT) Library. The modified version of SERVQUAL is used to measure perceptions and expectations of library users including faculty members, graduate and undergraduate students of CIIT library. For this purpose, a final sample of 281 respondents was used for analysing the data. The result of the study revealed that there is a disparity between the expectations and perceptions of respondents.

Asogwa, and et al., (2014) assessed the quality of services to users in academic libraries in developing countries using SERVQUAL model. The purpose of this study was to explore the service areas where the desires of library users are not met, discover the causes, and suggest corrective measures. For this, both primary and secondary sources were used for data collection. The SERVQUAL Questionnaire and the websites were used, and the research population was 3,832 library users from four developing countries. The data were analysed and discussed using descriptive statistics, and other illustrations. The study revealed that all the service indicators evaluated were negatively marked and there is a significant difference between the perceptions and expectations of library users. Lack of modern facilities, poor funding and weak leadership quality of library services are identified problems and not satisfying users expectations.

Another study was conducted by Enayati and et al., (2013) for evaluating service quality in Islamic Azad University of Mazandaran through descriptive survey. For this study, the statistical population consists of all Islamic Azad University students of Mazandaran and 373 students were chosen through stratified random sampling method. The modified SERVQUAL standardized questionnaire used as the tool for gathering data. The study investigated that there is a significant difference between the students' expectations and perceptions in all five 
dimensions of service quality and in all dimensions, student ${ }^{\text {ee }}$ expectations had a higher level than that of the perceptions.

The first user survey in University libraries of Srilanka to assess service quality conducted by Somaratna and Peiris (2011). Users of Colombo University Library surveyed by using modified version of SERVQUAL to ascertain the views about service level. They were subjected to measure the actual service delivered by the library and their expectations form the service oriented institution.

The study was carried out by Sahu (2007) to evaluate service quality of Jawaharlal Nehru University (JNU) library using SERVQUAL. The main purpose of the study was to measure the perceptions of the Jawaharlal Nehru University (JNU) library users as they relate to quality service and to determine how far the JNU library has succeeded in delivering such service to its users. The population of the study was students and faculty members of the JNU. All the closed ended structured questions were designed to elicit responses on a five point Likert scale to measure both respondent satisfaction and perception of service quality. The researcher applied chi-square method for analysis of the collected data and findings shows that the JNU library is not lacking in quality of service.

Manjunatha and Shivalingalah (2004) gives information about concept and development of service quality, it"s dimensions and SERVQUAL through their article "Customer"s perception of Service Quality in Libraries." The aim of the study was to investigate the quality of services from customeres perspectives in eight academic libraries in Karnataka. Thesample population of the study was faculty members, research scholars and post graduate students and used modified SERVQUAL questionnaire for data collection. The findings of the study revealed that among five dimensions, the reliability ranked as the most important dimension followed by responsiveness.

The similar study was done by using SERVQUAL conducted by Nimsomboon and Nagata (2003) in Thailand. They subjected Thamssat University Library System to examine service quality. The study surveyed undergraduate, graduate students and faculty members.

\section{RESEARCH METHODOLOGY}

The purpose of the study is to examine user perception and expectation on library service quality from dimensions like library information resources, services and facilities that are available for use in Krishna Kanta Handiqui Library, Gauhati University. The present study is to assess the expected and perceived service quality of university system library.

The study is quantitative in nature and convenient sampling method has been used to fulfil the objectives of the study using a structured questionnaire. 5-point Likert scale was used where the respondents were asked to select the most appropriate number that correspondents to extent to which they agree with a statement. The scales in the survey questions is 1 to 5 where " 1 " means "strongly disagree" and "5" means "strongly agree". There are several software packages for the analysis of quantitative data, but for this research SPSS and Microsoft excel was used. The respondents of the survey were post graduates students of the respective university.

\section{DATA ANALYSIS AND INTERPRETATION}

The present study is an attempt to assess service quality of Gauhati University Library System. The statements have included in the questionnaire based on five dimensions such as Reliability, Assurance, Tangible, Empathy and Responsiveness. The survey is to gather information on the following points based on five dimensions such as,

- Tangible: The appearance of physical facilities, equipments, personnel and communication materials in the library. 
- Reliability: The ability of library personnel to perform the promised service dependably and accurately.

- Responsiveness: The willingness of library staff to help customers and provide prompt service.

- Assurance: The knowledge and courtesy of the library staff and their ability to inspire trust and confidence among users.

- Empathy: The provision of caring and individualized attention to customers.

The first issue to be addressed in service gap analysis is that the gap between customers expectations and perceptions. This gap occurs when there is discrepancy between customers expectations and perceptions. Therefore to ensure good quality the service provider must at least meet or else exceed customers expectations.

The tables below presents the means and gap scores computed for each item of service quality dimensions. The gap score for each item was computed by deducting mean expectation from mean perception.

Table 1 Physical facilities, equipment's, communication materials and appearance of Library staff

\begin{tabular}{|c|c|c|c|c|c|c|}
\hline \multicolumn{3}{|l|}{ Perception } & \multicolumn{3}{|l|}{ Expectation } & \multirow[t]{2}{*}{ Gap Score } \\
\hline & Valid & Mean & & Valid & Mean & \\
\hline $\begin{array}{c}\text { Library has adequate } \\
\text { space with enough seating } \\
\text { capacity }\end{array}$ & 99 & 3.91 & $\begin{array}{c}\text { Do you think enough } \\
\text { seating capacity help users } \\
\text { to study? }\end{array}$ & 99 & 3.76 & 0.152 \\
\hline $\begin{array}{c}\text { Stack room signs are easy } \\
\text { to understand }\end{array}$ & 99 & 3.39 & $\begin{array}{l}\text { Are Stack room signs } \\
\text { important in a library? }\end{array}$ & 99 & 3.99 & -0.596 \\
\hline $\begin{array}{l}\text { Library staffs are smart } \\
\text { neat and good looking } \\
\text { appearance }\end{array}$ & 99 & 2.94 & $\begin{array}{c}\text { Do you think smart neat and } \\
\text { good looking appearance of } \\
\text { library staffs help for a } \\
\text { positive environment in the } \\
\text { library? }\end{array}$ & 99 & 4.18 & -1.242 \\
\hline $\begin{array}{l}\text { Library provides easy } \\
\text { access to e-resources by } \\
\text { using modern technology }\end{array}$ & 99 & 3.27 & $\begin{array}{c}\text { Should Library provide easy } \\
\text { access to e-resources by } \\
\text { using modern technology? }\end{array}$ & 99 & 4.18 & -0.909 \\
\hline $\begin{array}{l}\text { Ventilation and lighting is } \\
\text { good }\end{array}$ & 99 & 3.42 & $\begin{array}{l}\text { Ventilation and lighting } \\
\text { should be good? }\end{array}$ & 99 & 4.42 & -1.000 \\
\hline Total & & 3.387 & 0 & & 4.107 & -0.719 \\
\hline
\end{tabular}


Measuring Service Quality in Gauhati University Library: A Servqual Analysis

Table 2 Ability of library professionals to perform the promised services dependably and accurately

\begin{tabular}{|c|c|c|c|c|c|c|}
\hline \multicolumn{3}{|l|}{ Perception } & \multicolumn{3}{|l|}{ Expectation } & \multirow[t]{2}{*}{ Gap Score } \\
\hline & Valid & $\begin{array}{c}\text { Mea } \\
\text { n }\end{array}$ & & Valid & Mean & \\
\hline $\begin{array}{l}\text { Library staff making } \\
\text { efforts to know } \\
\text { customers and their } \\
\text { needs }\end{array}$ & 99 & 2.58 & $\begin{array}{l}\text { Do you think library staff } \\
\text { should make efforts to } \\
\text { know customer needs? }\end{array}$ & 99 & 4.42 & -1.848 \\
\hline $\begin{array}{l}\text { Library staff responds } \\
\text { clearly and accurately to } \\
\text { enquiry of user }\end{array}$ & 99 & 3.06 & $\begin{array}{l}\text { Should the library staff } \\
\text { respond clearly and } \\
\text { accurately to enquiry of } \\
\text { users? }\end{array}$ & 99 & 4.32 & -1.263 \\
\hline $\begin{array}{c}\text { Some library staffs are } \\
\text { impolite }\end{array}$ & 99 & 3.06 & $\begin{array}{c}\text { Does impolite behaviour of } \\
\text { library staffs effect the } \\
\text { users? }\end{array}$ & 99 & 4.56 & -1.495 \\
\hline $\begin{array}{c}\text { There is no inter library } \\
\text { loan facility }\end{array}$ & 99 & 3.27 & $\begin{array}{l}\text { Should there be inter } \\
\text { library loan facility? }\end{array}$ & 99 & 3.89 & -0.616 \\
\hline Total & & 2.992 & & & 4.298 & -1.306 \\
\hline
\end{tabular}

Table 3 Analysis to knowledge and courtesy of library staff

\begin{tabular}{|c|c|c|c|c|c|c|}
\hline \multicolumn{2}{|c|}{ Perception } & \multicolumn{2}{c|}{ Expectation } & Gap score \\
\hline $\begin{array}{c}\text { Library staff use the } \\
\text { technology quickly and } \\
\text { skillfully }\end{array}$ & 99 & 3.03 & $\begin{array}{c}\text { Do you think it is necessary } \\
\text { that Library staff should use } \\
\text { the technology quickly and } \\
\text { skillfully? }\end{array}$ & 99 & 4.36 & \\
\hline $\begin{array}{c}\text { Library staff has the } \\
\text { knowledge to ask users } \\
\text { questions }\end{array}$ & 99 & 3.00 & $\begin{array}{c}\text { Should the Library staff } \\
\text { have the knowledge to ask } \\
\text { users questions? }\end{array}$ & 99 & 4.32 & -1.333 \\
\hline $\begin{array}{c}\text { Library staffs are always } \\
\text { polite and who in still } \\
\text { develop confidence in } \\
\text { users }\end{array}$ & 99 & 3.00 & $\begin{array}{c}\text { Does the polite behaviour of } \\
\text { Library staff develop } \\
\text { confidence in users? }\end{array}$ & 99 & 4.28 & -1.323 \\
\hline
\end{tabular}


Digbijoy Das and Kaushik Handique

\begin{tabular}{|c|c|c|c|c|c|c|}
$\begin{array}{c}\text { Library staff assures } \\
\text { records of personal } \\
\text { information be safe from } \\
\text { unauthorized users }\end{array}$ & 99 & 3.64 & $\begin{array}{c}\text { Is it necessary that Library } \\
\text { staff assures records of } \\
\text { personal information be safe } \\
\text { from unauthorized users? }\end{array}$ & 99 & 4.09 & -0.455 \\
\hline $\begin{array}{c}\text { I feel safe and secure } \\
\text { when I enter in to the } \\
\text { library }\end{array}$ & 99 & 4.15 & $\begin{array}{c}\text { Should you feel safe and } \\
\text { secure when you enter into } \\
\text { the library? }\end{array}$ & 99 & 4.37 & \\
\hline Total & & 3.36 & & & 4.287 & -0.923 \\
\hline
\end{tabular}

Table 4 Analysis of caring and individualized attention by library professionals to users

\begin{tabular}{|c|c|c|c|c|c|c|}
\hline \multicolumn{3}{|l|}{ Perception } & \multicolumn{3}{|l|}{ Expectation } & \multirow[t]{2}{*}{ Gap Score } \\
\hline & Valid & Mean & & Valid & Mean & \\
\hline $\begin{array}{c}\text { Library staffs who } \\
\text { understands the needs of } \\
\text { users }\end{array}$ & 99 & 3.36 & $\begin{array}{c}\text { Do you think Library staff } \\
\text { should understand the need } \\
\text { of the users? }\end{array}$ & 99 & 4.39 & \\
\hline & & & & & & -1.030 \\
\hline $\begin{array}{l}\text { Library staffs reminds me } \\
\text { about overdue books }\end{array}$ & 99 & 3.12 & $\begin{array}{c}\text { Is it necessary that the Library } \\
\text { staffs remind you about } \\
\text { overdue books? }\end{array}$ & 99 & 4.31 & \\
\hline & & & & & & -1.192 \\
\hline $\begin{array}{c}\text { Library staffs assists me in } \\
\text { database searching }\end{array}$ & 99 & 2.97 & $\begin{array}{c}\text { For effective searching should } \\
\text { library staffs have knowledge } \\
\text { about database searching? }\end{array}$ & 99 & 4.33 & \\
\hline & & & & & & -1.364 \\
\hline $\begin{array}{c}\text { Library staff provides } \\
\text { individual attention to users }\end{array}$ & 99 & 2.45 & $\begin{array}{l}\text { Is it necessary that library } \\
\text { staff provide individual } \\
\text { attention? }\end{array}$ & 99 & 3.95 & \\
\hline & & & & & & -1.495 \\
\hline $\begin{array}{l}\text { Opening hours are more } \\
\text { convenient to users }\end{array}$ & 99 & 3.03 & $\begin{array}{l}\text { Should Opening hours be } \\
\text { more convenient to users? }\end{array}$ & 99 & 4.22 & \\
\hline & & & & & & -1.192 \\
\hline Total & & 2.988 & & & 4.242 & -1.255 \\
\hline
\end{tabular}


Table 5 Analysis to willingness of library professionals to help users and provide prompt service

\begin{tabular}{|c|c|c|c|c|c|c|}
\hline \multicolumn{3}{|l|}{ Perception } & \multicolumn{3}{|c|}{ Expectation } & \multirow{2}{*}{$\begin{array}{c}\text { Gap } \\
\text { Score }\end{array}$} \\
\hline & Valid & Mean & & Valid & Mean & \\
\hline $\begin{array}{c}\text { Library staff informs me } \\
\text { about new services and } \\
\text { collections }\end{array}$ & 99 & 2.21 & $\begin{array}{c}\text { Is it necessary Library staff } \\
\text { should inform users about new } \\
\text { services and collections? }\end{array}$ & 99 & 4.54 & -2.323 \\
\hline $\begin{array}{c}\text { Library staffs intimates me } \\
\text { about availability of reserved } \\
\text { books }\end{array}$ & 99 & 2.36 & $\begin{array}{c}\text { Should the Library staffs } \\
\text { intimate users about availability } \\
\text { of reserved books? }\end{array}$ & 99 & 4.12 & -1.758 \\
\hline $\begin{array}{c}\text { Library staff have willingness } \\
\text { to help users at anytime }\end{array}$ & 99 & 2.97 & $\begin{array}{l}\text { Do you think the attitude of } \\
\text { willingness of Library staff to } \\
\text { help users at any time is good? }\end{array}$ & 99 & 4.34 & -1.374 \\
\hline $\begin{array}{l}\text { Library staffs are not ready } \\
\text { to respond users inquiries }\end{array}$ & 99 & 2.61 & $\begin{array}{l}\text { Should library staffs be ready } \\
\text { to respond to users inquiries? }\end{array}$ & 99 & 4.36 & 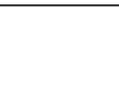 \\
\hline $\begin{array}{l}\text { Library staffs seeks users } \\
\text { suggestion in the preparation } \\
\text { of bibliographies, stack room } \\
\text { guides etc }\end{array}$ & 99 & 2.27 & $\begin{array}{c}\text { Do you think Library staffs } \\
\text { should seek users suggestion } \\
\text { in the preparation of } \\
\text { bibliographies, stack room } \\
\text { guides etc? }\end{array}$ & 99 & 4.18 & -1.909 \\
\hline Total & & 2.485 & & & 4.309 & -1.824 \\
\hline
\end{tabular}

The negative gap scores in the following tables indicates the existence of deficiency in service quality as customers expectations were not adequately met by the service provided. The wider negative gap shows a serious deficiency and more dissatisfaction of customers with the quality of service rendered. Hence, this issue demands library professionals closer attention so as to make improvement in service performance outputs. The above tables demonstrates the gap scores on 99 items which was supposed to measure the service quality of the library system. Here the gap scores of all items except for one are negative which indicates that the library system were not doing enough in meeting users expectations. However the gap score of the regarding adequate space is positive. This indicates that the users are satisfied with the space available in the library and helps users to study.

The maximum negative gap score is for the willingness of library professionals to help users and provide prompt service (-1.824). This implies that the library professionals are not willing to help the users. On the other hand the minimum gap score is for the physical facilities, equipment's, communication materials and appearance of Library staff $(-0.719)$ ie.the users are satisfied with the physical facilities and equipments available in the library. They are also pleased with the appearance of library staff. 


\section{FINDINGS}

The findings of the study can be used as a guide for library management to improve the crucial quality attributes and enhance service quality and performance of the library.

- The study revealed that the users desired expectations are not met in the prevailing Service delivery of Krishna Kanta Handiqui Library.

- The study shows that majority of users in the Krishna Kanta Handiqui Library are satisfied with physical facilities.

- The study revealed that users in the library needs individual attention from library staff and they expect more assistance for their information requirements.

- It is found that the desired service expectations are lagged behind the actual service perceptions.

- It revealed that the staff attributes of service quality don't meet user's expectations.

- Though the library provides e-resources, users don't get convenient accessibility.

Findings also show that the users expected more than what they perceive and this lead to no satisfaction so university must act to improve all dimensions/statements of service quality in order to get higher perceived service quality and customer satisfaction.

\section{CONCLUSION}

As a service oriented institution, Gauhati University Library system must satisfy the ever growing needs of its end users and should provide quality products or services. The system facilitates teaching, learning and research, it also provides sources and services and products. But, the study reveals that all attributes of service quality don't meet user's expectations. The users, post graduate students have expectations from library staff, they should be service mind and politeness. They also need individual attention and support from them. Gauhati University Library should enhance extension activities to aware new services and conduct training sessions for easy accessibility of e-resources.

\section{REFERENCES}

[1] Asogwa, Brendon, E. (2014). Use of SERVQUAL in the Evaluation of Service Quality of Academic Libraries in Developing Countries. Library Philosophy and Practice e journal, 1/46

[2] Calvert, P. (2001). International variations in measuring customer expectations. Library Trends , 19 (4), 1-25.

[3] Enayati, T. et al., (2013). Measuring Service Quality of Islamic Azad University of Mazandaran using SERVQUAL Model. Iranian Journal of Management Studies (IJMS), 6(1), 99-116.

[4] Forrest, C. (2009). Academic Libraries as learning spaces: Library effectiveness and the user experience. Georgia Library Quarterly : , 46 (3), 1-12.

[5] Gama, U. G. (2013). Reference Services in the Digital Age: What hoep for reference librarians in Nigeria. Bayero Journal of Library and Information Sciences , 1 (1), 32-39.

[6] Hernon, P. (2002). Quality: New directions in the research. The Journal of Academic Librarianship , 28, 224-231

[7] Irohan, C.O. et al., (2017). Service Quality Delivery of facilities in Covenant University Lecture Theatre: Assessing End User"es Satisfaction. Covenant Journal of Research in the Built Environment (CJRBE), 5(1). 
[8] Kulkarni, M., \& Deshpande, N. J. (2012). Empowering Library Users, Establishing Channel of Communication for Service Quality Expectations of Trainers from Government Administrative Training Institute (ATI) Libraries in India. World Library and Information Congress 78th IFLA General Conference and Assembly (pp. 1-17). Helsinki: IFLA.

[9] Malik, S. A. \& Malik, S. A. (2015). SERVQUAL to measure perceptions and expectations of library users: a case study of a Public University Library of Pakistan. http:/ doi. Org/10.1504/IJMIE 2015070124

[10] Manjunatha, K. \& Shivalingalah, D. (2004). Customeres perception of Service Quality in Libraries. Annals of Library and Information Studies, 51(4), 145-151.

[11] Nimsomboon, N. \& Nagata, H. (2003). Assessment of Service Quality at Thammasat University Library System Research Project, University of LIS, Japan.

[12] Nitechi, D. A. (1996). Changing the concept and measure of Service Quality in Academic Libraries. The Journal of Academic Librarianship, 22(3), 181-190.

[13] Parasuraman, A., Zeithaml, V., \& Berry, L. (1985). A conceptual model of Service Quality and Its Implications for Future Research. Journal of Marketing, 49, 41-50.

[14] Peris, W. K., \& Otike, J. (2016). Non Use of Academic Library Services: A Literature Review . International Journal of Library Science, 1-7. 